\title{
Clinical Features of Patients with Carcinomatous Meningitis in the Chinese Population: Report of 4 Cases and Review of the Literature
}

\author{
Cin Popülasyonunda Karsinomatöz Menenjitli Hastalarn Klinik \\ Özellikleri: 4 Olgu Sunumu ve Literatürün Gözden Geçirilmesi
}

\author{
Hao DUAN ${ }^{1}$, Mei LI², Xiaojiang SUN ${ }^{1}$ \\ ${ }^{1}$ Shanghai 6th People's Hospital Affliated to Shanghai Jiao Tong University, Internal Medicine, Department of Neurology, Shanghai, \\ China \\ ${ }^{2}$ Shanghai 6th People's Hospital Affiliated to Shanghai Jiao Tong University, Department of Radiology, Shanghai, China
}

Corresponding Author: Xiaojiang SUN / E-mail: duanhao_sh@sina.com.cn

\begin{abstract}
AIM: Carcinomatous meningitis (CM) is a rare neurological disorder. We aim to promote the diagnostic efficiency of CM.

MATERIAL and METHODS: Four patients (1 male and 3 females) who had been diagnosed with CM from June 2007 to June 2009 in our department were included in this study. The mean age of those patients was 55.25 years. Clinical presentation, magnetic resonance imaging findings, cerebrospinal fluid (CSF) and serum tumor markers were examined.

RESULTS: CM may present with acute or subacute onset of symptoms. Intracranial hypertension and meningeal irritation were common in patients with CM. Other symptoms included neck and occipital pain, unilateral lower limb weakness and abnormalities of the cranial nerves. Other unusual symptoms included impaired vision ( 2 cases), bilateral sensorineural hearing loss (1 case), and continuous roaring in both ears ( 1 case). MRI revealed contrast enhancement in the meninges in 3 cases. CSF cytology was positive for cancer cells in 2 cases. The survival of patients ranged from 18 days to 8 months.
\end{abstract}

CONCLUSION: Patients with CM may present with a variety of symptoms. Serum tumor biomarker determination, CSF cytology, and contrastenhanced MRI scan are essential in the diagnosis of CM.

KEYWORDS: Carcinomatous meningitis, Diagnosis, Imaging

öz

AMAÇ: Karsinomatöz menenjit (KM) nadir bir nörolojik bozukluktur. KM için tanısal etkinliği arttırmayı amaçlıyoruz.

YÖNTEM ve GEREÇLER: Haziran 2007 ile Haziran 2009 arasında bölümümüzde KM tanısı konan dört hasta (1 erkek ve 3 kadın) bu çalışmaya dahil edildi. Hastaların ortalama yaşı 55,25 yıldı. Klinik durum, manyetik rezonans görüntüleme bulguları, beyin omurilik sıvısı (BOS) ve serum tümör işaretleri incelendi.

BULGULAR: KM akut veya subakut belirtilerle ortaya çıkabilir. İntrakraniyal hipertansiyon ve meningeal iritasyon bulguları KM hastalarında sıktı. Başka belirtiler arasında boyun ve oksipital ağrı, tek taraflı alt uzuv zayıfığı ve kraniyal sinir anormallikleri vardı. Diğer olağandışı belirtiler arasında görme bozukluğu (2 olgu), bilateral sensörinöral işitme kaybı (1 olgu) ve her iki kulakta sürekli uğuldama (1 olgu) vardı. MRG 3 olguda meninkslerin kontrast tuttuğunu gösterdi. BOS sitolojisi 2 olguda kanser hücreleri açısından pozitifti. Hastaların sağkalımı 18 gün ile 8 ay arasındaydı.

SONUÇ: KM hastaları çeşitli belirtilerle gelebilir. Serum tümör biyobelirteci saptanması, BOS sitolojisi ve kontrastlı MRG tarama KM tanısında şarttır.

ANAHTAR SÖZCÜKLER: Karsinomatöz menenjit, Tanı, Görüntüleme

\section{INTRODUCTION}

Carcinomatous meningitis (CM), also known as meningeal carcinomatosis, neoplastic meningitis, and leptomeningeal carcinoma, is a rare neurological disorder caused by the seeding of cancer cells into the central nervous system (CNS) via the cerebrospinal fluid (CSF). Characterized by multifocal involvement of the cranial nerves and spinal nerve roots, it represents a devastating complication of systemic cancer, and patients with CM have a poor prognosis and increased mortality.

$\mathrm{CM}$ is diagnosed in $1-5 \%$ of patients with solid tumors. Breast carcinoma, lung carcinoma, and melanoma are the most common tumors that may metastasize to the meninges; CM has been estimated to occur in $2.5-5 \%$ of breast cancers, 
9-25\% of small cell lung cancers, and $23 \%$ of melanomas $(28,23,1)$. However, the number of people who develop CM is difficult to determine, as the reported incidence may be underestimated due to the difficulty in diagnosis.

Typically in CM there is diffuse infiltration of the meninges, and metastatic tumor cells may be found in the CSF. The disease affects different parts of the central nervous system. Patients with CM may present with headache, diplopia, hearing loss and facial numbness.

CM has been described in isolated case reports $(2,3,13)$. Clinical course and neuroimaging findings have not been investigated in detail in the Chinese population. Here we report 4 cases of $\mathrm{CM}$ in the Chinese population. The clinical features and neuroimaging findings were investigated.

\section{MATERIAL and METHODS}

The Review Board of our institution approved this study, and all patients gave written informed consent. Patients who were diagnosed with CM from June 2007 to June 2009 in our department were included in this study. The clinical presentation, serum tumor marker levels, magnetic resonance imaging (MRI), and CSF examination were evaluated.

\section{RESULTS}

A total of 4 patients were included in our study.

The first patient was a 49-year-old man who presented with right leg weakness that had persisted for one month. He had also experienced progressive vision loss during the previous two weeks, and a headache for 5 weeks. The headache was located in the neck and the occipital region, accompanied

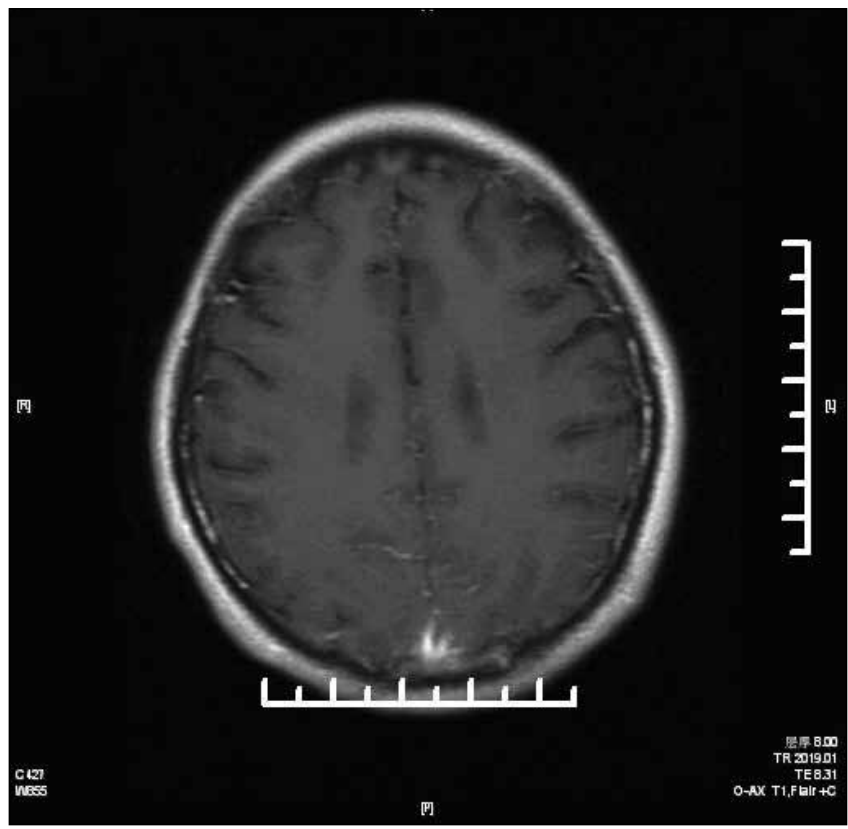

Figure 1: Contrast-enhanced T1-weighted axial MR image, showing leptomeningeal enhancement over the frontal and parietal lobes. by vomiting. On examination, bilateral abducens nerve palsy was observed. Muscle strength in the right leg was reduced.

Contrast-enhanced MRI of the brain was performed the day after admission. Gadolinium-enhanced T1-weighted imaging revealed high-intensity signals in the leptomeningeal of the frontal lobe, parietal lobe, and cerebellum (Figure 1, 2). Lumbar puncture was performed. The CSF results were: opening pressure $250 \mathrm{mmH}_{2} \mathrm{O}$, protein $0.77 \mathrm{~g} / \mathrm{L}$, glucose $2.32 \mathrm{mmol} / \mathrm{L}$, and Cl $124 \mathrm{mmol} / \mathrm{L}$. CSF cytology was normal. His serum glucose, serum carbohydrate antigen (CA) 724, alpha-fetoprotein (AFP), carcinoembryonic antigen (CEA), serum carbohydrate antigen 19-9 (CA19-9), and prostate specific antigen (PSA) were normal. Chest computed tomography (CT) showed pulmonary nodules in the posterior basal segment of the left lower lobe.

Three weeks after admission, bronchoscopy was performed and revealed a neoplasm at the posterior basal segment of the left lower lobe. The pathology report was suggestive of lung adenocarcinoma. The patient was diagnosed with lung cancer complicated by $\mathrm{CM}$. The patient had generalized tonicclonic seizures 12 days after admission. The patient died of cerebral herniation 25 days after admission.

The second patient was a 55-year-old woman who presented to our department with a one-month history of dizziness, headache, vomiting and progressive bilateral hearing loss. The patient also had right-sided facial palsy for one week before admission. The patient had been diagnosed with colon cancer and had undergone radical right colon resection 5 months before admission. She also received chemotherapy with oxaliplatin and 5-fluorouracil. On examination, the

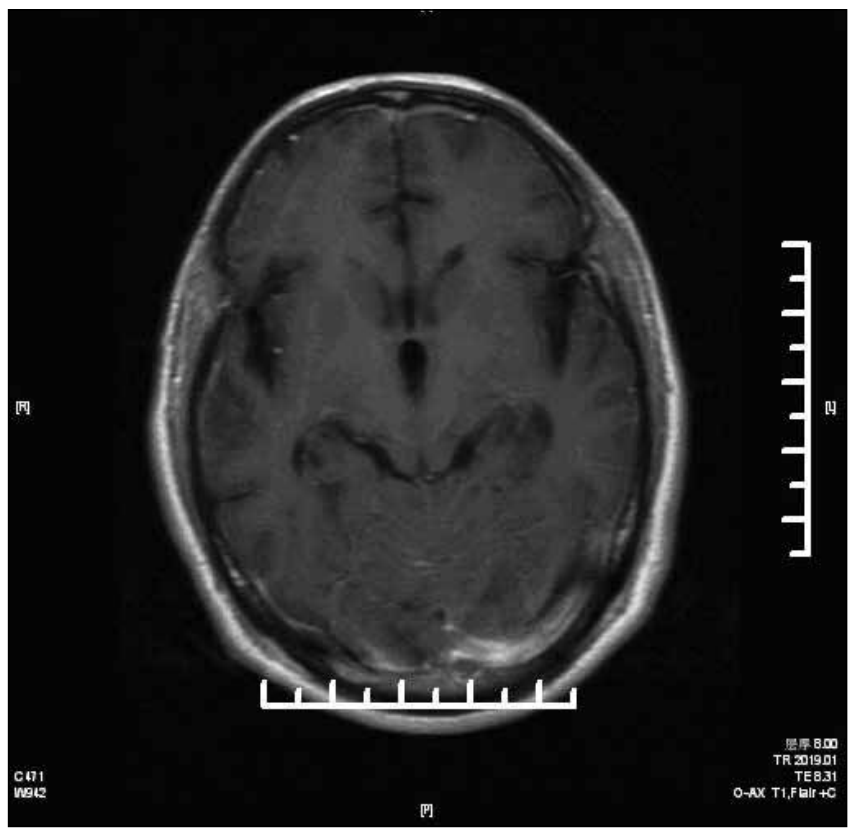

Figure 2: Contrast-enhanced T1-weighted axial MR image, showing leptomeningeal enhancement over the cerebellum. 
patient had right-sided facial palsy and was unable to close the right eye completely. Pure-tone audiometry revealed bilateral sensorineural hearing loss. MRI of the brain was performed on admission and did not reveal any abnormalities. Lumbar puncture was also performed upon admission and was as follows: revealed opening pressure $>400 \mathrm{mmH}_{2} \mathrm{O}, \mathrm{CSF}$ protein $0.42 \mathrm{~g} / \mathrm{L}$, glucose $4.01 \mathrm{mmol} / \mathrm{L}$, and $\mathrm{Cl} 109 \mathrm{mmol} / \mathrm{L}$. CSF cytology was normal. Her serum CA19-9 was $289.51 \mathrm{U} / \mathrm{L}$.

Hervision deteriorated afteradmission and shehadgeneralized tonic-clonic seizure attacks 9 days after admission. Enhanced MRI of the brain was performed 2 days after admission and showed bilateral leptomeningeal enhancement and signal abnormalities in the right cerebellopontine angle. Repeated report of the CSF cytology was positive for malignant cells in the patient. CM was diagnosed after the cytology test and the patient died of pneumonia 3 weeks later.

The third patient was a 57-year-old woman with breast cancer who underwent right breast resection in October 2007. She complained of headache, vomiting, and a continuous roaring in both ears when she was first seen on the $1^{\text {st }}$ of May 2008. There was no dizziness or otalgia. Physical examination was normal. Contrast-enhanced MRI of the brain was performed on May $5^{\text {th }}$, which showed no abnormality. Lumbar puncture was performed on May $5^{\text {th }}$. The results of lumbar puncture were: opening pressure $180 \mathrm{mmH}_{2} \mathrm{O}$, protein $1.92 \mathrm{~g} / \mathrm{L}$, glucose $0.80 \mathrm{mmol} / \mathrm{L}$, and Cl $109 \mathrm{mmol} / \mathrm{L}$. CSF cytology showed large numbers of poorly differentiated malignant cells. The patient was diagnosed with meningeal carcinomatosis according to the CSF results. On May $14^{\text {th }}$, MRI was repeated and showed contrast enhancement in the leptomeninges of the cerebellum (Figure 3, 4). Her magnetic resonance angiography (MRA) and magnetic resonance venography (MRV) were normal. Her serum CA19-9 value was elevated at $766.18 \mathrm{kU} / \mathrm{L}$. On May $12^{\text {th }}$, she had generalized tonic-clonic seizures. She died of cerebral herniation on May $18^{\text {th }}$

The last patient was a 60-year-old, non-smoking, previously healthy woman who complained of continuous pain in the occipital region and neck 2 months prior to admission. She also had intermittent nausea and vomiting. She was referred to our hospital with suspected cervical spondylosis on June $26^{\text {th }}$ 2009. On examination, neck stiffness was noticed. Her neurological examination was otherwise normal. From July $5^{\text {th }}$, she had several episodes of loss of consciousness for approximately 5-10 minutes. On July $9^{\text {th }}$, lumber puncture was performed and showed opening pressure of $235 \mathrm{mmH}_{2} \mathrm{O}$, protein content $0.27 \mathrm{~g} / \mathrm{L}$, glucose $1.90 \mathrm{mmol} / \mathrm{L}$, and $\mathrm{Cl} 111$ $\mathrm{mmol} / \mathrm{L}$. Her serum carcinoembryonic antigen (CEA) and CA19-9 values were $442.73 \mu \mathrm{g} / \mathrm{L}$ and $63.76 \mathrm{kU} / \mathrm{L}$, respectively. CT scan revealed diffuse pulmonary nodules (Figure 5). MRI of the brain was performed and showed no abnormality. On July $11^{\text {th }}$, her positron emission tomography (PET)-CT showed multiple miliary nodules in both lung fields. 2-(fluorine-18) fluoro-2-deoxy-d-glucose (FDG) metabolism was increased in the meninges, suggesting meningeal metastasis. Based on PET-CT results, CM was suspected. Thoracoscopic cytology

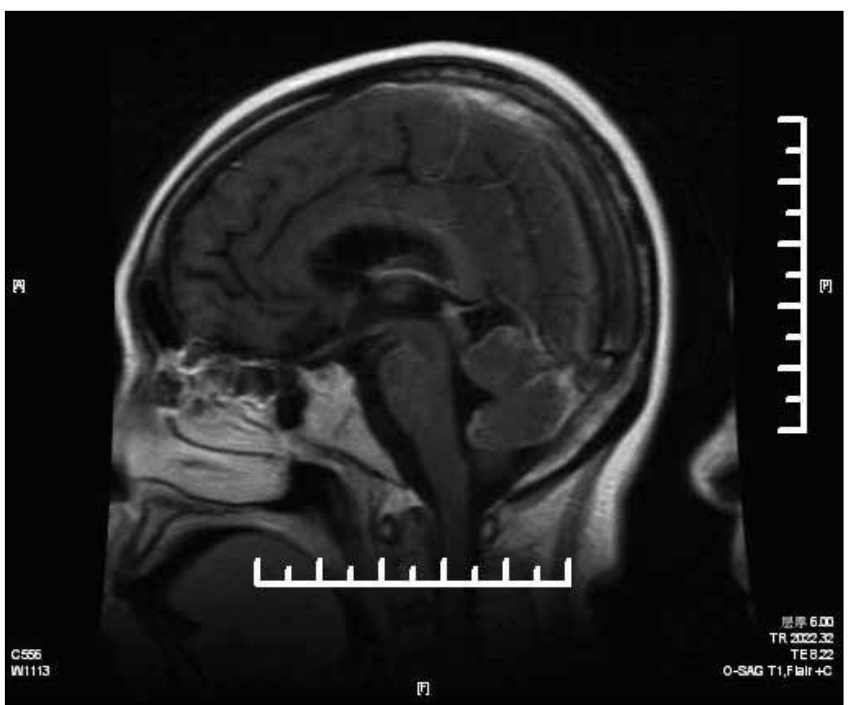

Figure 3: Contrast-enhanced T1-weighted sagittal MR image, showing leptomeningeal enhancement over the cerebellum.

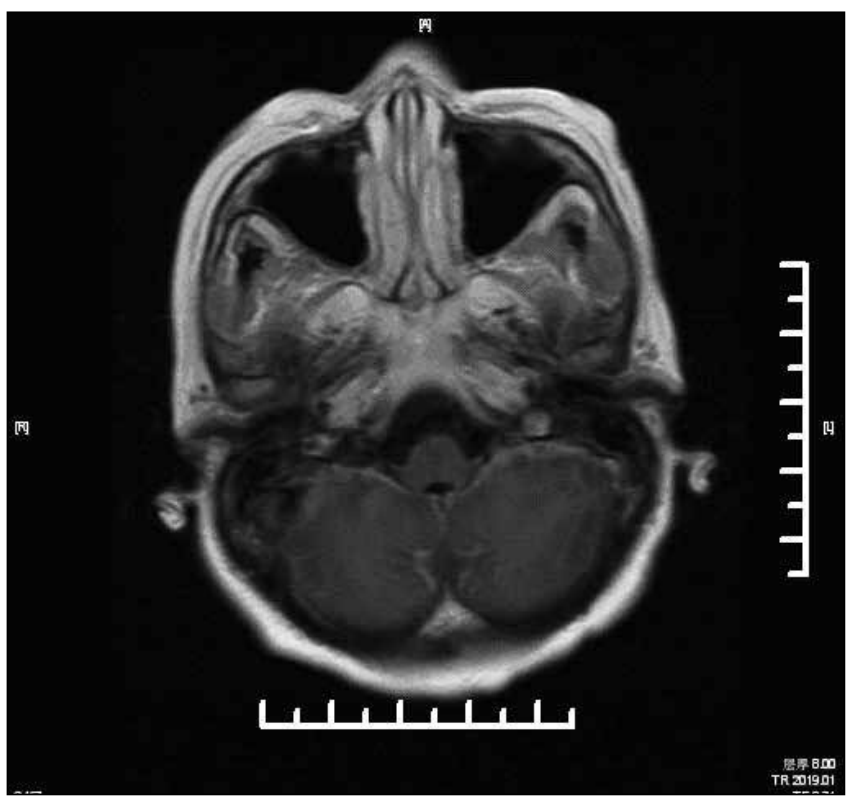

Figure 4: Contrast-enhanced T1-weighted axial image, showing leptomeningeal enhancement over the cerebellum.

was positive for bronchioloalveolar carcinoma. The patient died 6 months later.

\section{DISCUSSION}

CM is an important complication of cancer. A previous study suggested that up to $8 \%$ of patients with cancers will develop CM (21). The frequency is highly dependent on the type of primary cancer. CM is especially common in patients with lymphoma, leukemia, breast, small cell lung cancer, and melanoma $(9,20,27)$. Rarer causes of CM include carcinoid cancer, and cancers of the renal cell, head and neck squamous cell, prostate, and thyroid (14). 


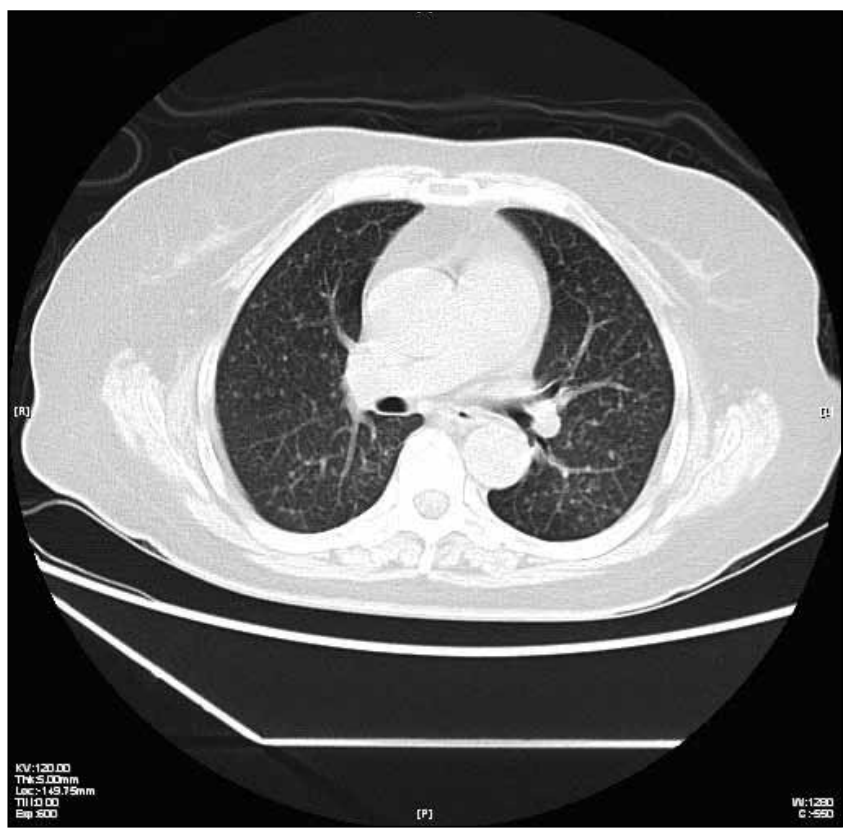

Figure 5: Chest CT shows diffuse pulmonary nodules.

The meninges consist of the pia-arachnoid (leptomeninges), and dura (pachymeninges) mater membranes, which are bathed in CSF. Pathological evidence suggests that tumor cells may reach the leptomeninges by hematogenous spread to the vessels of the arachnoid or to the choroid plexus, and by direct infiltration of the subarachnoid space from intraparenchymal, dural, and bone-based metastases. Tumor cells may also follow a perineurial route along cranial nerves to enter the subarachnoid space, a pathway mainly encountered in head and neck cancers. CM can also develop following surgical resection of cerebellar metastases upon accidental dissemination of tumor cells into the CSF (16).

Patients typically present with neurological dysfunction at multiple levels of the nervous system, usually in the setting of a known malignancy. Often, signs on examination are more frequently noticed than symptoms (14). Involvement of the CNS is frequent in the cerebrum, cranial nerves and leptomeninges. Cerebral involvement usually presents with headache, nausea, encephalopathy, and seizures. Increased intracranial pressure and communicating hydrocephalus may be present and manifest with incontinence or gait disturbance. Cranial nerve involvement usually presents with diplopia. Other symptoms include impaired vision, sensory deficits, facial weakness, hearing loss, and vertigo. Solid tumor-derived leptomeningeal metastases have a higher affinity for the optic and extraocular nerves, while leukemic and lymphomatous meningitis preferentially affect the facial nerve (14). Spinal root involvement is caused by either meningeal irritation, which may presented with nuchal rigidity and neck and back pain. This may also be due to invasion of the spinal roots (usually lumbar), causing leg weakness and paresthesias (14).
In our study, 4 patients had acute or subacute onset of symptoms that progressively deteriorated. Intracranial hypertension was present in all 4 cases, which presented with headache and vomiting. Other common symptoms included neck and occipital pain (cases 1 and 4). Interestingly, patients with CM may also present with limb weakness (case 1) and abnormalities of the cranial nerves (cases 1 and 2). Other unusual symptom included continuous roaring in both ears (cases 4).

The diagnosis of $\mathrm{CM}$ is often difficult, and based on our experience, clinical presentation is important. CM should be considered in patients with a history of cancer who present with a new onset of headaches that are not explained by other causes. Headache has been documented in patients with $\mathrm{CM}$ in other studies, but the location and progression of the headache have not been described in detail. In our study, headache was a common presenting symptom. The headache usually occurred gradually and was exacerbated during disease progression. We found that the headache was located around the neck and occipital region. Our study also suggests that visual symptoms and hearing complaints are relatively common in patients with $\mathrm{CM}$.

Notably, we observed that generalized tonic-clonic (grand mal) seizures are common in patients with $\mathrm{CM}$, but are not a presenting symptom. We propose that the onset of seizures may indicate exacerbation of the disease. In fact, patients died very quickly after onset of seizures. All patients had repeated EEG and 24 hour EEG monitoring which suggested spikes and polyspike-and-slow-wave discharges. They had no history of epilepsy and family history of epilepsy. In our opinion, the seizures were secondary to the $\mathrm{CM}$.

In patients with suspected CM, serum tumor markers, MRI, and lumbar puncture should be performed.

MRI may be considered as a screening test in patients suspected of CM. Repeated gadolinium-enhanced T1weighted MRI is also important for diagnosis, especially in patients with negative CSF cytology. MRI was reported to have a higher sensitivity than CT scan. In a retrospective study, MRI was positive in approximately $80 \%$ of $\mathrm{CM}$ originating from solid tumors, but in only $53 \%$ of cases with hematological origin (24).

The CSF cytology remains the gold standard for CM diagnosis. It may be negative in the first lumbar puncture, however, repeated lumbar punctures can increase the yield. Some studies indicate that CSF tumor marker evaluation may provide a reliable means and surrogate end-points of monitoring response of carcinomatous meningitis to treatment (6).

$\mathrm{CM}$ is usually fatal. Therefore, the main treatment goal is to reduce pain and prevent further neurological decline. Leukemia and lymphoma usually respond better to treatment than solid tumors. Corticosteroids are effective in treating acute spinal or cranial nerve compression; steroids are particularly helpful in improving headache and radicular pain. 
CM is treated with either radiation or intrathecal chemotherapy. Currently, methotrexate and cytarabine are administered for intrathecal treatment. Recent evidence suggests that CM originating from lung cancer could be treated with gefitinib $(25,10,7,18)$ and high-dose erlotinib (19) One study also suggested that trastuzumab may benefit some CM patients who had breast cancer (11). Recently, several authors reported successful treatment of meningeal carcinomatosis by intrathecal trastuzumab $(17,22,26)$. Some studies indicate that radiotherapy (whole brain and involved-field irradiation of bulky spinal lesions) and chemotherapy (systemically or intrathecally applied methotrexate, thiotepa, and cytarabine) are both effective and may prolong survival from several weeks to 4-6 months in patients with CM $(8,4)$. It was found that CSF cytology or MRI alone would have missed leptomeningeal disease in as many as $14 \%$ to $18 \%$ patients. Therefore, patients with a clinical syndrome or neuroradiographic findings that suggest CM should be treated in a similar fashion as those patients with cytologically proven $\mathrm{CM}(5)$.

A recent single-center retrospective study of 155 patients with CM reported a median survival of 4.8 months (12). In our study, we found the survival of our patients ranged from 18 days to 8 months. In this case series, all CM patients had seizure before death. Epilepsy appears to be one of the warning signals of deterioration. The diagnosis of $\mathrm{CM}$ is made by correlating physical signs and symptoms with laboratory findings and neuroimaging studies. Early diagnosis can provide effective palliation and prolong survival (15).

\section{REFERENCES}

1. Aroney RS, Dalley DN, Chan WK, Bell DR, Levi JA: Meningeal cancer in small cell carcinoma of the lung. Am J Med 7: 26-32, 1981

2. Amer MH, Al-Sarraf M, Baker LH, Vaitkevicius VK: Malignant melanoma and central nervous system metastases: Incidence, diagnosis, treatment and survival. Cancer 42: 660-668, 1978

3. Bowen $C D$, Von Burton G, Bargen RC, Madonia P, Zhang S, Toledo EG, Zweig R, Pant C: Carcinomatous meningitis secondary to transitional cell bladder cancer. South Med J 103: 809-812, 2010

4. Bruna J, González L, Miró J, Velasco R, Gil M, Tortosa A: Leptomeningeal carcinomatosis: Prognostic implications of clinical and cerebrospinal fluid features. Cancer 115:381-389, 2009

5. Bomgaars L, Chamberlin M, Poplack D: Leptomeningeal metastases. In Levin V (ed). Cancer in the Nervous System, 2nd. New York: Oxford University Press 2002:373-393

6. Kosmas C, Tsavaris NB, Tsakonas G, Soukouli G, Gassiamis A, Mylonakis N, Karabelis A: Cerebrospinal fluid tumor marker levels in predicting response to treatment and survival of carcinomatous meningitis in patients with advanced breast cancer. Med Sci Monit 11(8): CR398-401, 2005
7. Fukuhara $T$, Saijo $Y$, Sakakibara $T$, Inoue A, Morikawa $N$, Kanamori M, Nakashima I, Nukiwa T: Successful treatment of carcinomatous meningitis with gefitinib in a patient with lung adenocarcinoma harboring a mutated EGF receptor gene. Tohoku J Med 214:359-363, 2008

8. Feyer $\mathrm{P}$, Sautter-Bihl ML, Budach W, Dunst J, Haase W, Harms W, Sedlmayer F, Souchon R, Wenz F, Sauer R: DEGRO practical guidelines for palliative radiotherapy of breast cancer patients: Brain metastases and leptomeningeal carcinomatosis. Radiotherapy Strahlenther Onkol 186: 63-69, 2010

9. Hrrlinger U, Förschler H, Küker W, Meyermann R, Bamberg M, Dichgans J, Weller M: Leptomeningeal metastasis: Survival and prognostic factors in 155 patients. J Neurol Sci 223: 167-178, 2004

10. Hashimoto N, Imaizumi $K$, Honda T, Kawabe T, Nagasaka T, Shimokata K, Hasegawa Y: Successful re-treatment with gefitinib for carcinomatous meningitis as disease recurrence of non-small-cell lung cancer. Lung Cancer 53:387-390, 2006

11. Stemmlera HJ, Mengele K, Schmitt M, Harbeck N, Laessig D, Herrmann KA, Schaffer $P$, Heinemann V: Intrathecal trastuzumab (Herceptin) and methotrexate for meningeal carcinomatosis in HER2-overexpressing.metastatic breast cancer:a case report. Anti-Cancer Drugs 19: 832-836, 2008

12. Herrlinger $U$, Förschler $H$, Küker W, Meyermann R, Bamberg M, Dichgans J, Weller M: Leptomeningeal metastasis: Survival and prognostic factors in 155 patients. J Neurol Sci 223: 167-178, 2004

13. Juan Vidal O, de Paz Arias L, Catalá Barceló J, García Escrig M: Meningeal carcinomatosis as first manifestation of carcinoma of the bladder: Report of 2 cases (in Spanish). An Med Interna 17:425-428, 2000

14. Drappatz J, Batchelor TT: Leptomeningeal and peripheral nerve metastases. American Academy of Neurology 11(5): 47-68, 2005

15. Drappatz J, Batchelor TT: Leptomeningeal metastasis. American Society of Clinical Oncology 100-105, 2009

16. Kokkoris CP: Leptomeningeal carcinomatosis. How does cancer reach the pia-arachnoid? Cancer 51: 154-160, 1983

17. Laufman LR, Forsthoefel KF: Use of intrathecal trastuzumab in a patient with carcinomatous meningitis. Clin Breast Cancer 2: 235,2001

18. Kanaji N, Bandoh S, Nagamura N, Kushida Y, Haba R, Ishida T: Significance of an epidermal growth factor receptor mutation in cerebrospinal fluid for carcinomatous meningitis. Internal medicine (Tokyo, Japan) 46(19): 1651-1655, 2007

19. Dhruva N, Socinski MA: Carcinomatous meningitis in nonsmall-cell lung cancer: Response to high-dose erlotin. Journal of Clinical Oncology 27(22): e31-e32, 2009

20. Olson ME, Chernik NL, Posner JB: Infiltration of the leptomeninges by systemic cancer. A clinical and pathologic study. Arch Neurol 30: 122-137, 1974

21. Posner JB, Chernik NL: Intracranial metastases from systemic cancer. Adv Neurol 19: 579-592, 1978 
22. Platini C, Long J, Walter S: Meningeal carcinomatosis from breast cancer treated with intrathecal trastuzumab. Lancet Oncol 7: 778-780, 2006

23. Rosen ST, Aisner J, Makuch RW, Matthews MJ, Ihde DC, Whitacre M, Glatstein EJ, Wiernik PH, Lichter AS, Bunn PA Jr: Carcinomatous leptomeningitis in small cell lung cancer: A clinicopathologic review of the National. Cancer Institute Experience. Medicine (Baltimore) 61: 45-53, 1982

24. Strik HM, Proemmel P, Pilgram-Pastor S, Buhk JH: Neoplastic meningitis - is MRI as sensitive as CSF cytology? J Clin Oncol 27: 9566, 2009 (May 20 Supplement, No 15S)

25. Sakai $M$, Ishikawa $S$, Ito $H$, Ozawa $Y$, Yamamoto $T$, Onizuka $M$, Sakakibara Y: Carcinomatous meningitis from non-smallcell lung cancer responding to gefitinib. Int J Clin Oncol 11: 243-245, 2006
26. Stemmler HJ, Schmitt M, Harbeck N,Willems A, Bernhard H, Lassig D: Application of intrathecal trastuzumab (Herceptin) for treatment of meningeal carcinomatosis in HER2overexpressing metastatic breast cancer. Oncol Rep 15: 1373-1377, 2006

27. Wasserstrom WR, Glass JP, Posner JB: Diagnosis and treatment of eptomeningeal metastases from solid tumors: Experience with 90 patients. Cancer 49: 759-772, 1982

28. Yap HY, Yap BS, Tashima CK, DiStefano A, Blumenschein GR: Meningeal carcinomatosis in breast cancer. Cancer 42: 283-286, 1978 